\title{
Anchoring Innovations through Aetiology
}

\author{
Annette Harder
}

\section{Introduction}

As we can see in this volume, aetiology is a popular concept. It is found all through Greek and Roman history in a great variety of sources, including poetry. ${ }^{1}$ Generally speaking, it helps to create a firm basis for the present in the past by showing that the present is the result or continuation of what happened or was begun in the past. ${ }^{2}$ Thus a story from the past can be used as a means of legitimizing or explaining the present and of creating a sense of roots and continuity, i.e. of 'anchoring' the present, often against a religious, ideological or political background. We can find examples of this in poets like Pindar, Aeschylus and Euripides and in the Homeric hymns, but the device becomes increasingly popular with poets of the Hellenistic period, when the need to legitimize new institutions by framing them as part of an ongoing tradition seems to have been stronger than ever, and is then taken up by the Romans for whom aetiology became an important tool to shape their own past in connection with their ambitious present.

With respect to the aetiological passages discussed in this chapter, basically the pattern is that something is there and that you explain and foreground it by relating it to an event in the past which caused the present situation. Many examples of this kind of aetiology are found at the end of plays by Euripides, where a deus ex machina often announces a ritual following from the events in the play. $^{3}$ In this way the distant world of the play is connected with the present of the audience, for which this ritual is still part of the present. A

1 For a brief survey with further references see Harder 2012, vol. 1, 24-27. See also Loehr 1996 (with a useful theoretical survey of the concept on pp. 3-38); Asper 2013; for interesting observations about aetiology and identity the chapter on 'Aetiology Overseas' in Kowalzig 2007 and for the connections between aetiology and religion Waldner 2014. On aetiology before Callimachus Codrignani 1958 is still useful.

2 See also Loehr 1996, 30: “Aitiologie' (mythisch) bezeichnet ... die Verbindung eines real-existierenden, gegenwärtigen Sachverhaltes mit einem Ereignis in der Vergangenheit, das die $U r$-Sache ist. Diese $U r$-Sache ist Zentrum des Sachverhaltes, denn sie fixiert und legitimiert ihn ...".

3 See e.g. Dunn 1996 and 200o; Scullion 2000. 
typical example is Ion 1581-1588 where Athena predicts the future of Ion's descendants - sketching a future of Athenian expansion which at the time of performance around 413 BCE might seem somewhat utopic:

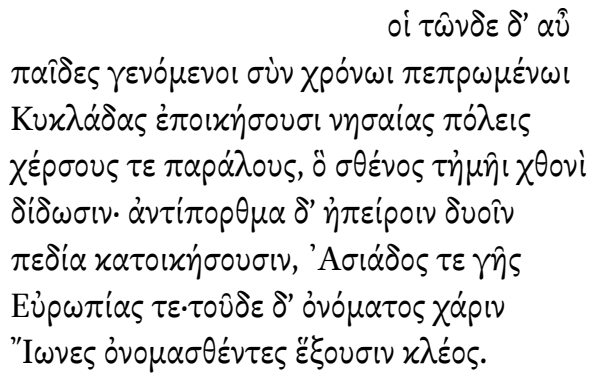

They in their turn shall have sons who in the appointed course of time shall found cities on the islands of the Cyclades and on the mainland coasts, to lend their strength to my city. They shall colonize the lowlands on either side of the strait that divides Europe from Asia; called after this prince, they shall bear the glorious name of Ionians.

transl. P. VELLACOTT

In Hellenistic and Roman narrative poetry one finds different ways of presenting the aitia. There it is the narrator who connects past and present on behalf of his readers and in these cases one can start either from the present, explaining that something is still as it is today because of what happened in the past, or one can start from the past, drawing attention to the fact that traces of the events from the past are still present in the world of today (often with the words हैं $\tau$ vôv 'even now' drawing attention to the connection of past and present). The first approach we find in the Aetia of Callimachus, where present rituals are causing surprise and lead to questions (particularly in the first two books) and are subsequently explained with stories from the past, as, e.g., in fr. 3.1-2, where the aition of the Charites at Paros starts with the question why sacrifices to them are without flutes and wreaths. The second we find in the Argonautica of Apollonius Rhodius, where many episodes in the Argonauts' journey end with a remark that traces of it are still visible today, as in, e.g., the aition of the anchor at Cyzicus in A.R. 1.955-960. ${ }^{4}$

In this chapter we will explore the possibilities of aetiology as regards the way in which it can be used in poetry as a tool to anchor contemporary innovations in a mythical past as well as to anchor future institutions by casting

4 See further Harder 2003 and 2012, vol. 1, 25. 
events in the present as their aition, and we will look at the way in which aitia that have become obsolete can be 'recycled' to fit a new context. These uses of aetiology suggest that in antiquity there was an ongoing awareness of its religious, ideological and political possibilities and also of the vitality and versatility of the concept: both form and contents could be adapted to new circumstances and adjusted in order to be effective there.

Aetiology and Innovation

As indicated in the introduction, aetiology is not only used to anchor a well-established present and to draw attention to specific aspects of it, but one may also relate the concept of anchoring innovations to aetiology. According to this concept innovations can be made more acceptable to the general public by connecting them in a meaningful way to what was already there in order to create a sense of familiarity and continuity, which helps to accept the new institution or invention. ${ }^{5}$ In connection with aetiology we may distinguish various ways of anchoring innovations: anchoring the present in the past, anchoring the future in the present and anchoring by means of recycling.

\section{Anchoring the Present in the Past}

Sometimes we see that a new or future institution in the present is linked to an aetiological story from the past and presented as sanctioned by these events, as if it were a continuation of something that had been predicted a long time ago or had in some way been there all the time. Another example from Euripides may serve to show how this could be achieved. This is the passage about the alliance of Athens and Argos at the end of Euripides' Supplices, where Athena as deus ex machina explains that in repayment for the help offered by Theseus Adrastus must swear an oath (E. Supp. 1191-1195):

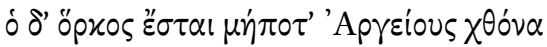

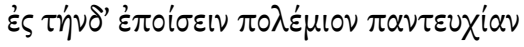

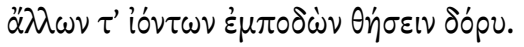

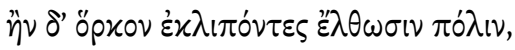

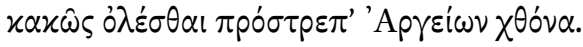

5 On the concept of 'anchoring innovation' see in general Sluiter 2017. 
And this shall be the form of the oath: 'Never shall Argives march against Attica in arms; if others march, Argos shall interpose her sword. And if they break their oath and march, then let them bring down upon Argos shame, destruction and defeat.'

transl. P. VELLACOTT

As Collard in his commentary on 1165-1234 and in his introduction observes, ${ }^{6}$ the actual phrasing reflects that of contemporary peace treaties. He plausibly argues that it is likely that Euripides conceived this play and the speech of Athena "when an Athens-Argos alliance was one possible direction of Athenian diplomacy", and, in fact, in 420 BCE an alliance between Argos and Athens was made. So here we may observe how a new step in current war diplomacy was given a basis in the past by means of an aetiological passage. ${ }^{7}$

Two further points are worth observing here: (a) the aetiological explanation acquires extra authority because, as in the example from the Ion quoted above, it is the deus ex machina who is announcing it; (b) from a chronological point there is an interesting ambiguity, because this divinity and the watching audience operate at different moments in time: on the one hand the aetiology refers to an institution which for the audience is part of their present or, in the case of the Supplices, of their near future, on the other hand it is predicted by a divinity from the distant past for whom this institution is still in the future. Basically this means that the god or goddess in his or her present is shaping the past of his or her own future, of which, being immortal, they will inevitably be part too; this future, then, overlaps with the present or future of the audience. Thus the gods are presented as helping later generations, such as the audience in the theatre, to accept the innovations by anchoring them in their past and sanctioning them by their divine authority. Their physical presence as a character on stage in the theatre helps to underline this authority and to blur the distance in time.

A good example of anchoring a new institution from the Hellenistic period is the way in which Apollonius Rhodius ends his Argonautica in 4.1730-1764 with a passage explaining how the descendants of the Argonauts came to North Africa and settled in Cyrene. ${ }^{8}$ Euphemus dreams that he breast-fed and slept with a clod of earth, given to him by Triton (4.1552-1563), which turned

6 Collard 1975, 10-11 and 406-423.

7 On the political dimensions of this episode see also, e.g., Hose 2008, 77-78.

8 On aitia in Apollonius Rhodius see in general Valverde Sanchez 1989, who discusses the aition of the clod of Euphemus on pp. 266-269; and more recently Klooster 2014. 
into a woman. This woman tells him that she is a daughter of Triton and Libya and nurse of his children and asks to be thrown into the sea near Anaphe. From there she promises to rise again as a home for Euphemus' descendants. When he tells his dream to Jason, Jason remembers a prophecy by Apollo and explains that the clod, which is part of the Libyan land, will become an island (Thera) where the descendants of Euphemus will live (A.R. 4.1749-1754): ${ }^{9}$

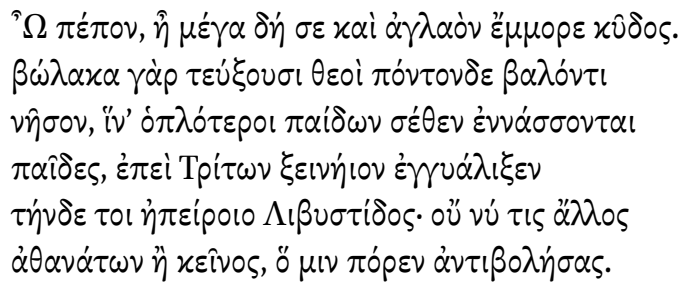

Truly, my dear friend, great and glorious fame has been allotted to you, for after you cast the clod into the sea, the gods will turn it into an island, where later generations will dwell, because Triton gave you this piece of the Libyan mainland as a guest-gift. It was he and no other of the immortals, who met us and gave it to you.

transl. W.H. RACE

Euphemus then throws the clod into the sea. Then the island Calliste emerges, where the descendants of Euphemus, driven from Lemnos to Sparta and travelling from there to Calliste, led by Theras, will live. They will then call the island Thera. Apollonius leaves out the sequel, which must have been familiar for his readers from Pindar's Fourth Pythian Ode and Herodotus (4.150-158) and was also told by Callimachus in his Hymn to Apollo: that from Thera Cyrene in Libya was colonized, which brought the Greeks to North Africa. Although in the time of Apollonius the Greeks had been in Cyrene for a long time (Hdt. 4.159 adds how many Greeks migrated to Cyrene), this story may also help to legitimize the still relatively new widespread presence and rule of the Greeks in Egypt in the third century BCE as well as explain the lasting importance of Cyrene, while showing how these later Greeks are part of a continuous Greek tradition that began well before the Trojan War. ${ }^{10}$ This is more straightforward than the tragic examples, as the reader and the narrator may be regarded as operating

$9 \quad$ See on this passage now Hunter 2015, 312sq. and his commentary on the individual lines. See also Jacqueline Klooster's contribution to this volume.

See e.g. Stephens 2000, esp. 201-203; Mori 2008, 112; Klooster 2014, 533-535. 
at the same moment in time. It should be noticed, though, that the narrator, when quoting Jason, refers to a divine authority at some length, so that the prediction as it were gains status and may thus convince the readers as well as the Argonauts. Thus the epic seems to recall the device of the deus ex machina from tragedy as a way to sanction the aetiological connection by means of a prophecy by a divine authority at the end of a literary work.

It also seems that what Apollonius is doing here inspired aetiological aspects of Vergil's Aeneid. ${ }^{11}$ The notion of a character from an epic story and his offspring having impact on the present recurs when in Aeneid 6.724-887 Anchises is prophesying how the animae of selected dead, who have been purified, will return to a life on earth after a thousand years and will rule in Italy and Rome, beginning with Silvius, the son of Aeneas, and in the course of many generations will lead to Caesar and the Julian family of Augustus and the promising Marcellus, who would die at an early age. In the course of his long prophecy Anchises mentions many Roman kings and heroes by name and speaks about the expansion of the Roman empire, so compared to the brief and cryptic passage in the Argonautica the passage is long and elaborate. Still the same elements can be observed: in both texts there is a prophecy concerning a future settlement of ideological and political importance, connected with an epic character and his offspring, and this prophecy gains authority by the nature of the speaker, the dream fitting in with the prophecy by Apollo in the Argonautica and the venerable Anchises (who recalls Teiresias in Odyssey 11 and has a role in inspecting the animae in A. 6.677-683) in the Aeneid. A detail in the passage from the Aeneid, a simile in 707-709, where the souls of those who will get a second life, i.e. the future descendants of Aeneas, are compared to buzzing bees swarming around lilies in a field near the river Lethe, in a subtle way recalls not the end of the Argonautica, but the end of the Lemnian episode in A.R. 1.879-885, where the Lemnian women, swarming around the departing Argonauts and wishing them a good journey are compared to buzzing bees gathering honey around lilies in a dewy meadow. As will become clear at the end of the Argonautica, one of these Lemnian women will be the mother of the offspring of the Argonaut Euphemus.

11 Of course this is just one aspect of the many - and complex - connections between the Argonautica and the Aeneid, which within the compass of this article can be dealt with only briefly. On the Argonautica and the Aeneid see in general Hunter 1993, 170-189; Nelis 2001; Mori 2008, 224-235; on aetiology in the Aeneid also Binder 1988. 


\section{4}

\section{Anchoring the Future in the Present}

What we saw in the previous examples is that a character in the past is speaking and acting in a way that predicts and shapes a future which coincides with the present of the narrator and the reader. More experimentally, the present can also be cast as the past of the future by a speaker or narrator who, unlike the tragic deus ex machina and the characters in epic poetry, operates at the same moment in time as his audience: an event or action in the present will then provide a reason for a specific institution in the future and acquire, as it were, aetiological status.

This concept is briefly discussed and related to the example of aitia from the past in Aristophanes' Clouds, where in 1421-1424 Pheidippides challenges the authority of the old law and addresses his father as follows:

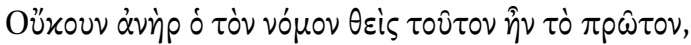

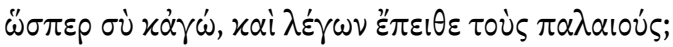

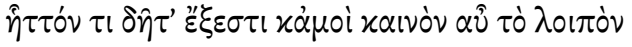

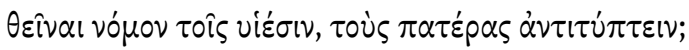

Well was not he who made the law, a man, a mortal man, as you or I, who in old times talked over all the crowd? And think you that to you or me the same is not allowed, to change it, so that sons by blows should keep their fathers steady?

transl. B. BICKLEY ROGERS

Here the aition of the old law is presented as an act of a man from the past and Pheidippides claims that the same is possible for him and that he in his turn can institute a new law for the future, emphasizing the aetiological and inno-

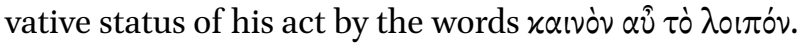

What Pheidippides suggests as a possible course of action is in fact done by Callimachus and Ovid, as we find this kind of proceeding in the catasterism of the lock of Berenice at the end of Callimachus' Aetia and in the apotheosis of Caesar at the end of Ovid's Metamorphoses. ${ }^{12}$ A closer look at these texts reveals that here too some extra authority seems to have been deemed necessary for making the aetiology convincing and giving it status. Thus the speaker in the Lock of Berenice is not just some mortal narrator, but the lock of Berenice herself. This lock was sacrificed for the safe return of Berenice's husband,

12 See for further discussion Harder 2003. 
Ptolemaeus III Euergetes, from the Syrian War and has just been lifted up to the realm of the stars and gods through the agency of Aphrodite and has thus acquired a divine status (fr. 110.52-64):

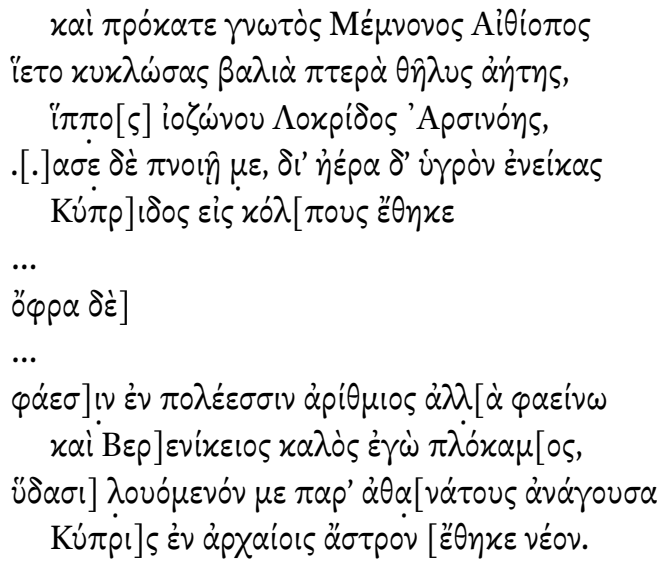

And straightaway the brother of the Ethiopian Memnon came rushing on, circling his swift wings, a gentle breeze, the Locrian horse of Arsinoe with her purple girdle, and took me with his breath, and carrying me through the humid air he placed me in Cypris' lap ... And in order that ... I would also shine, I, the beautiful lock of Berenice, Cypris brought me, washed in the water, to the immortals and placed me as a new star among the old ones.

transl. M.A. HARDER

From this authoritative position the lock demands an ongoing ritual of sacrifices to itself, recalling the rituals for the dead in tragedy (as in e.g. E. Hipp. 1423-1430), as we know from Catullus' translation of Callimachus' poem (Catul. 66.79-94), where the lock asks for sacrifices by young brides (7988 ) and by Berenice on festive days for Aphrodite (89-94). ${ }^{13}$ At the same time the lock's position, now that it has acquired a divine status among the stars, is comparable to that of the deus ex machina in tragedy. However, unlike these gods it is not speaking from the past, but shares the same moment in time with the audience and predicts their shared future.

13 For discussion of the fact that in Catullus lines 79-88 do not correspond to the remains of Callimachus' text in P. Oxy. 2258 see Harder 2012 on fr. 110.79-88. For the issue of anchoring a future institution in the present it does not really make a difference whether or not both rituals were originally part of (versions of) Callimachus' text. 
As Apollonius' aetiological technique may have inspired Vergil, so Callimachus' idea of casting the present as the past of the future may have been an example for Ovid in his Metamorphoses. ${ }^{14}$ In the apotheosis of Caesar (Ov. Met.15.745-879) the notion of a catasterism of a historical character at the end of a catalogue poem is reminiscent of the fate of the lock of Berenice in the Aetia, as the announcement of Caesar in 749 as sidus ... nouum stellamque comantem ('a new star and comet', but with a notion of coma 'lock of hair' in the adjective, which recurs in 849 crinem 'tail of hair') clearly suggests by recalling Callimachus' $\alpha \sigma \tau p o v$... [véov] immediately at the beginning of the episode. ${ }^{15} \mathrm{At}$ the same time the narrative technique of the passage in Ovid and the emphasis on the intervention of the gods also recalls the Argonautica. As in the Argonautica the events are told by the narrator, but arranged by the gods, so here too there is a great deal of divine agency, again recalling the device of the tragic deus ex machina. It is Venus who puts herself in charge of the apotheosis of Caesar, ${ }^{16}$ when she cannot prevent him being murdered and is aware of the need to provide Augustus with a divine ancestor. Consequently in 15.818-842 Jupiter promises that Caesar will become a god and promises victory to Augustus. Then Venus asks to turn Caesar's soul into a star and in $843-85$ o she actually brings his soul to the stars:

Vix ea fatus erat, media cum sede senatus
constitit alma Venus nulli cernenda suique
Caesaris eripuit membris nec in aera solvi
passa recentem animam caelestibus intulit astris
dumque tulit, lumen capere atque ignescere sensit

14 On the aetiological character of the Metamorphoses see in general Myers 1994; Waldner 2007; on Callimachus and Augustan aetiological elegy, including Propertius and Ovid, see Miller 1982.

15 Interestingly, it has been suggested that Ov. Met. 1.438-451, about Apollo slaying Python and founding the Pythian Games with the wreath of oak leaves as a prize, as the laurel does not yet exist (but will at the end of the following story about Apollo and Daphne), may refer to Callimachus' Victory of Berenice with the aition of the wreath at the Nemean Games at the beginning of Aetia 3; see Loehr 1996, 139-141; Waldner 2007, 215. If so, the framing of the Metamorphoses by the story of Apollo and Python, which is the first story after the flood, and the apotheosis of Caesar would recall the framing of Aetia 3 and 4 between the two poems dedicated to Berenice. Besides, the story of Apollo and Python also is the first story of Aetia 4 (fr. 86-89a), so that in a way it frames that book with the Lock of Berenice at the end. Ovid's positioning of the Python story thus recalls both framing devices in the Aetia.

16 On the important role of Venus in the aetiological programme of the Fasti, in close connection with the role of the Charites in Callimachus' Aetia, see Walter 2014, 432-437 and passim. 
emisitque sinu: luna volat altius illa

flammiferumque trahens spatioso limite crinem

stella micat

Scarce had he spoken when fostering Venus took her place within the senate-house, unseen of all, caught up the passing soul of her Caesar from his body, and not suffering it to vanish into air, she bore it towards the stars of heaven. And as she bore it she felt it glow and burn, and released it from her bosom. Higher than the moon it mounted up and, leaving behind it a fiery train, gleamed as a star.

transl. J.F. MILLER

Thus Augustus is provided with a divine ancestor and a basis has been created for his own apotheosis. The episode ends in $868-870$ with a prayer for a long life and subsequent divine status for Augustus and in $871-879$ it is added that the poet too will rise above the stars and live for ever. ${ }^{17}$

So, in both cases events in the here and now or very recent past of the reader are cast as the causes of later institutions. Divine agency plays an important part and, as in the Argonautica, recalls the deus ex machina of tragedy, also because these passages are found towards the end of works. ${ }^{18}$

\section{5}

\section{Anchoring by Means of Recycling}

A somewhat problematic aspect of aetiological texts which are anchoring innovations may be their later reception, because at a certain moment they become 'antiquarian', as the innovations are no longer 'new'. When past and present in the texts are no longer those of the readers and when institutions

17 Perhaps we also have an example of casting present events as an aition of the future in P. Oxy. 63.4352, fr. 5 col. II 11-17, where after the death of Hadrian's lover Antinous Semele takes the young man as her husband and turns him into a new star (cf. 13 véov $\varphi \alpha \dot{\alpha}$ ) and Hadrian offers him a town (Antinoopolis) and the Nile gives him an island, so that Antinous' death leads to institutions in the future. However, as the papyrus is dated ca. $285 \mathrm{CE}$ (as after line 17 a paragraphus marks the beginning of a new poem or section which celebrates Diocletian), we cannot be sure that the poem was contemporary with the death of Antinous, even if - as seems likely - we have two separate poems. For some further discussion see Livrea 1999; Focanti 2018, 29-102, who opts for a single poem (see especially pp. $3^{2-34) \text {. }}$

18 On the use of divine authority in connection with aetiological stories see also Harries 1989 , especially $174^{-182}$ about gods and goddesses used to authenticate the aetiological stories about their festivals in Ovid's Fasti. 
which were once new have become old or obsolete, as e.g. in the case of the lock of Berenice discussed above, they lose their original function and become just 'stories'. Apparently there was some awareness of this in antiquity, as in several of the instances of anchoring innovations by means of aitia discussed in the sections above we can observe the interesting phenomenon of the aetiological stories being 'recycled' to serve new circumstances at a time when the original contexts have become something of the past. We can see this happening with the story of the Argonauts and the foundation of Cyrene, which was the theme of Pindar's Fourth Pythian Ode, where it was playing a part in a political discourse connected with the laudandus Arcesilas of Cyrene. In Apollonius Rhodius and Callimachus Arcesilas is no longer relevant and the foundation of Cyrene is then given new significance in the context of Ptolemaic Egypt. ${ }^{19}$

Also in the case of the lock of Berenice a 'history' of the re-use of the aition can be sketched. We have seen that Ovid recycled it in the context of imperial Rome, by means of his allusions to it in the episode of the apotheosis of Caesar at the end of the Metamorphoses. Between Callimachus and Ovid, however, two more steps in the 'history' of the aition can be discovered. The first is the version of Catullus in his poem 66, also mentioned above. Although Catullus presents this poem as a translation (in Catul. 65), there are several small changes. One of these is the end of the poem, where in Callimachus' text the temporal aspect of a shared present is emphasized again at the end of the poem, where the queen (probably Berenice) is addressed in a final farewell in fr. 110.94a. In the text of Catullus the poem ends with line 94 and there is no farewell, which seems to fit in with the fact that for him the topical aspect of the poem is no longer relevant and the interest of the aetiological story has become mainly antiquarian. Also his choice to include lines $79-88$ may be accounted for by the new situation (see further above). The second step is to be found in Vergil's Georgics, where the prologue includes a passage about the deification of Caesar (Verg. G. 1.24-42). Damien Nelis has recently offered a convincing picture of the connections between the Georgics and Callimachus' Aetia ${ }^{20}$ and pointed to the series of allusions in Verg. G. 1.32 nouum ... sidus to Catul. 66.64

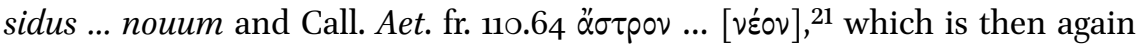
picked up in Ov. Met. 15.749 sidus ... nouum. It is striking that in Vergil's work the deification of Caesar is mentioned in the prologue instead of at the end of the work and that he does not tell an aetiological story. Even so the suggestion of a divinely sanctioned aition is there in the background through the allusions

\footnotetext{
19 On Apollonius' reworking of Pindar see particularly Stephens 2000, 201-203.

20 See Nelis 2013. For earlier work on Vergil and the Aetia see George 1974.

21 For another possible allusion to the Greek phrase see also n. 17.
} 
to the earlier texts and the variation on the pattern of the Aetia and the reader seems to be alerted anew to the political dimensions of the story of the lock of Berenice, which were absent in Catullus' version. Subsequently Ovid moved the deification to the end of his work again and added a new aetiological story, reminiscent of the original one, but fully adapted to the new context and elaborating the brief hint of Vergil. ${ }^{22}$

On the basis of these few examples aetiology in the hands of Greek and Latin poets can be regarded as an interesting way of anchoring not only the present as the status quo, but also of anchoring innovative elements of the present in the past as well as anchoring innovations for the future in the present, particularly on a religious, ideological and political level. In the case of anchoring innovations for the future in the present one might, on a conceptual level, speak of 'anticipatory aetiology' as a means of anchoring future innovations. The means used by the various poets discussed in this chapter to achieve these effects are well thought out and seem to aim at being as convincing as possible in order to get the new message across. One of the means to do this is to give the gods a leading role in the anchoring, either as proclaimers of a new situation being caused by earlier events or as the agents who direct more or less current events towards a desired purpose in the future and thus help to create a convincing aition. Besides, a creative use of intertextuality, relating the texts to earlier literary models, particularly in Greek tragedy, provides the gods themselves as agents of aetiology with the background of a long tradition. It anchors them as convincing authorities by drawing attention to the aetiology of their particular role in earlier texts. Another way of using intertextuality can be seen in the ways in which later authors adapt older aetiological stories to new circumstances, while still sharing in the authority of the earlier stories. ${ }^{23}$

22 An interesting attempt concerning the recycling of stories from Callimachus' Aetia has also been made by Peter Bing (2019), who shows that in late antiquity Aristaenetus adapted the love stories of Acontius and Cydippe and Phrygius and Pieria from Callimachus' Aetia in such a way that, while the Callimachean aitia anchored the concept of a happy royal marriage in a Ptolemaic context, his letters 1.10, 1.15 and 1.19 by subtle adaptations did the same for the royal couple of Aristaenetus' own age. Here, however, the focus is slightly different as it is not so much the actual aitia as the idea of love as a beneficial power that is the point at hand.

23 It would be useful to explore more aetiological texts, Greek as well as Latin, from this angle in order to acquire a larger picture and to refine the results of this brief investigation. Besides, also other aspects of aetiology in relation to anchoring innovation would be 


\section{Bibliography}

Asper, M. (2013). Minding the Gap. Aetiology and (False) Closure. In: F. Grewing, B. Acosta-Hughes and A. Kirichenko, edd., The Door Ajar. False Closure in Greek and Roman Literature and Art. Heidelberg: Winter, pp. 63-82.

Binder, G. (1988). Aitiologische Erzählung und augusteisches Programm in Vergils Aeneis. In G. Binder, ed., Saeculum Augustum, vol. 2: Religion und Literatur. Darmstadt: Wissenschaftliche Buchgesellschaft, pp. 255-287.

Bing, P. (2019). Thanks again to Aristaenetus. In: A. Harder, J. Klooster, R. Regtuit and G. Wakker, edd., Callimachus Revisited. New Perspectives in Callimachean Scholarship. Leuven: Peeters, pp. 27-49.

Codrignani, G. (1958). L'aition nella poesia greca prima di Callimaco. Convivium, 26, pp. $527-545$.

Collard, C. (1975). Euripides Supplices. Groningen: Bouma's Boekhuis.

Dunn, F.M. (1996). Tragedy's End. Closure and Innovation in Euripidean Drama. New York/Oxford: Oxford University Press.

Dunn, F.M. (2000). Euripidean Aetiologies. Classical Bulletin, 76, pp. 3-27.

Focanti, L. (2018). The Fragments of Late Antique Patria. Diss. Ghent/Groningen.

George, E. (1974). Aeneid VIII and the Aitia of Callimachus. Leiden: Brill.

Harder, A. (2003). The Invention of Past, Present and Future in Callimachus' Aetia. Hermes, 131(3), pp. 290-306.

Harder, A. (2012). Callimachus. Aetia, vol. 1: Introduction, Text, and Translation, vol. 2: Commentary. Oxford: Oxford University Press.

Harries, B. (1989). Causation and the Authority of the Poet in Ovid's Fasti. Classical Quarterly, 39(1), pp. 164-185.

Hose, M. (2008). Euripides. Der Dichter der Leidenschaften. Munich: C.H. Beck.

Hunter, R. (1993). The Argonautica of Apollonius. Cambridge: Cambridge University Press.

Hunter, R. (2015). Apollonius of Rhodes. Argonautica Book IV. Cambridge: Cambridge University Press.

Klooster, J. (2014). Time, Space, and Ideology in the Aetiological Narratives of Apollonius Rhodius' Argonautica. In: Reitz/Walter 2014, pp. 519-544.

Kowalzig, B. (2007). Singing for the Gods. Performances of Myth and Ritual in Archaic and Classical Greece. Oxford: Oxford University Press.

worth exploring, e.g. the way in which choices are made concerning the question which aspects of the present or future to anchor in which past among the - increasingly - many and sometimes contradictory stories of the past that were available; the various political or cultural contexts of this kind of aetiology; further aspects of the use of divine organizers and/or speakers to sanction the aition and its innovative outcome. 
Livrea, E. (1999). Chi è l'autore di P. Oxy.4352? Zeitschrift für Papyrologie und Epigraphik, 125, pp. 69-73.

Loehr, J. (1996). Ovids Mehrfacherklärungen in der Tradition aitiologischen Dichtens. Stuttgart/Leipzig: Teubner.

Miller, J. (1982). Callimachus and the Augustan Aetiological Elegy. Aufstieg und Niedergang der römischen Welt, II 30.1, ed. W. Haase, Berlin/New York: De Gruyter, pp. 371-417.

Mori, A. (2008). The Politics of Apollonius Rhodius' Argonautica. Cambridge/New York: Cambridge University Press.

Myers, K. (1994). Ovid's Causes. Cosmogony and Aetiology in the Metamorphoses. Ann Arbor: University of Michigan Press.

Nelis, D. (2001). Vergil's Aeneid and the Argonautica of Apollonius Rhodius. Leeds: Francis Cairns.

Nelis, D. (2013). Dichtung und Politik in Vergils Georgica (transl. W. Polleichtner). In: M. Baumbach and W. Polleichtner, edd., Innovation aus Tradition: Literaturwissenschaftliche Perspektiven der Vergilforschung. (BAC - Bochumer Altertumswissenschaftliches Colloquium 93). Trier: Wissenschaftlicher Verlag Trier, pp. ${ }^{-3} 3^{6}$.

Reitz, C. and Walter, A. (2014). Von Ursachen sprechen. Eine aitiologische Spurensuche Telling Origins. On the Lookout for Aetiology. Hildesheim: Olms.

Scullion, S. (2000), Tradition and Invention in Euripidean Aitiology, in: M.J. Cropp, ed., Euripides and Tragic Theatre in the Late Fifth Century. Champaign: University of Illinois, pp. 217-233.

Sluiter, I. (2017). Anchoring Innovation. A Classical Research Agenda. European Review, 25(1), pp. 20-38.

Stephens, S. (2000). Writing Epic for the Ptolemaic Court. In: A. Harder, R. Regtuit and G. Wakker, edd., Apollonius Rhodius. Leuven/Paris et al.: Peeters, pp. 195-215.

Valverde Sanchez, M. (1989). El aition en las Argonauticas de Apolonio de Rodas. Murcia: Universidad, Secretariado de Publicaciones.

Waldner, K. (2007). Griechische und römische Aitiologie in Ovids Metamorphosen. In: A. Bierl, R. Lämmle and K. Wesselmann, edd., Literatur und Religion. Wege zu einer mythisch-rituellen Poetik bei den Griechen, vol. 2. Berlin/New York: De Gruyter, pp. $203^{-237 .}$

Waldner, K. (2014). Aitiologie und Religion in der griechisch-römischen Antike. In: Reitz/Walter 2014, pp. 25-57.

Walter, A. (2014). Ovids alma Venus, die Mutter der Aitiologie. In: Reitz/Walter 2014, pp. 431-459. 